\title{
Living and lost mammals of Rio de Janeiro's largest biological reserve: an updated species list of Tinguá
}

\author{
Leandro Travassos $^{1 *}$ (D), Israel Dias Carvalho ${ }^{2}$, Alexandra S. Pires ${ }^{2}$, Sérgio Nunes Gonçalves ${ }^{1}$, Paulo \\ Malvino Oliveira ${ }^{3}$, Alexandre Saraiva ${ }^{4}$ \& Fernando A. S. Fernandez ${ }^{5}$ \\ ${ }^{1}$ Universidade Federal do Rio de Janeiro, Programa de Pós-Graduação em Ecologia, Associação Ecocidade, \\ Rua Comendador Silva Cardoso $n^{\circ} 5$ quadra 03, Pilar, Duque de Caxias, RJ, Brasil \\ ${ }^{2}$ Universidade Federal Rural do Rio de Janeiro, Instituto de Florestas, Departamento de Ciências Ambientais, \\ Rio de Janeiro, Rodovia BR 465 - Km 7, Seropédica, RJ, Brasil \\ ${ }^{3}$ Reserva Biológica do Tinguá - ICMBio, Estrada do Comércio 3400, Tinguá, Nova Iguaçu, Rio de Janeiro, Brasil \\ ${ }^{4}$ Superintendência da Polícia Federal - Regional Maranhão, São Luís, MA, Brasil \\ ${ }_{5}^{5}$ Universidade Federal do Rio de Janeiro, Departamento de Ecologia, Rio de Janeiro, RJ, Brasil \\ *Corresponding author: Leandro Travassos, e-mail: travassosleandro@gmail.com
}

TRAVASSOS, L., CARVAlHO, I. D., PIRES, A. S., GONÇALVES, S.N., OLIVEIRA, P. M., SARAIVA, A., FERNANDEZ, F. A. S. Living and lost mammals of Rio de Janeiro's largest biological reserve: an updated species list of Tinguá. Biota Neotropica 18(2): e20170453, 2018. http://dx.doi.org/10.1590/1676-0611BN-2017-0453

\begin{abstract}
The Tinguá Biological Reserve (TBR) is the largest protected area of this category in Rio de Janeiro state. Here, for the first time, we present the historical composition of terrestrial mammals' assemblage of TBR region. An inventory was conducted using transect surveys, nonstandard transects, survey of museum specimens and informal reports. Considering all the data, eighty-five species were recorded, placing TBR as the second one in the number of mammals recorded in "Serra do Mar" ecoregion of Atlantic Forest and in the Rio de Janeiro state. Among the species with historical records are the jaguar (Panthera onca) and the golden-lion-tamarin (Leontopithecus rosalia) while the current presence of the maned wolf (Chrysocyon brachyurus) was recorded for the first time. Priority studies should focus on Chiroptera, Rodentia and Didelphimorphia orders, especially in the most remote areas of the reserve, and long-term surveys of endangered species. Besides hunting, fragmentation of its interior by roads, pipelines and transmission lines and exotic species, TBR is also threatened by the urban growth around it and the pressure to reduce its area and its protection category, demanding greater attention by the high levels of governance of protected areas in Brazil.
\end{abstract}

Keywords: Mammal community, Atlantic Forest, Tinguá Biological Reserve, endangered species, museum data.

\section{Mamíferos atuais e extintos na maior Reserva Biológica do Rio de Janeiro: uma lista atualizada de espécies do Tinguá}

Resumo: A Reserva Biológica Tinguá (RBT) é a maior área protegida desta categoria no estado do Rio de Janeiro. Aqui, pela primeira vez, apresentamos a composição histórica da assembleia de mamíferos terrestres da região da RBT. Um inventário foi realizado utilizando amostragem por transectos, transectos não padronizados, busca por espécimes em museu e relatos. Considerando todos os dados, foram registradas oitenta e cinco espécies, colocando a RBT como a segunda no número de mamíferos registrados na ecorregião "Serra do Mar" da Mata Atlântica e no estado do Rio de Janeiro. Entre as espécies com registros históricos estão a onça-pintada (Panthera onca) e o mico-leão-dourado (Leontopithecus rosalia), enquanto a presença atual do lobo-guará (Chrysocyon brachyurus) foi registrada pela primeira vez. Estudos prioritários devem se concentrar nas ordens de Chiroptera, Rodentia e Didelphimorphia, especialmente nas áreas mais remotas da reserva, e pesquisas de longo prazo sobre espécies ameaçadas de extinção. Além da caça, a fragmentação em seu interior por estradas, gasodutos e linhas de transmissão e a presença de espécies exóticas, a TBR é ameaçada também pelo crescimento urbano no entorno e pela pressão para reduzir sua área e categoria de proteção, exigindo maior atenção dos altos níveis de gestão de áreas protegidas no Brasil.

Palavras-chave: comunidade de mamíferos, Mata Atlântica, Reserva Biológica de Tinguá, espécies ameaçadas de extinção, dados de museu. 


\section{Introduction}

In the last decades tropical forests have lost several vertebrate species due to anthropogenic impacts, especially habitat loss and fragmentation (Laurance et al. 2002, Ferraz et al., 2003), hunting (Parry \& Peres 2015), biological contamination (Lessa et al. 2016 ) or by the synergy between these processes (Peres 2001, Chiarello 1999, 2000, Cullen Jr. et al. 2000, 2000, 2004). This resulted in defaunated areas (Peres \& Laake, 2003, Travassos 2011, Dirzo et al., 2014, Ripple et al. 2015), that can cover large extensions (Canale et al. 2012, Galetti et al. 2016), where several ecological processes mediated by locally extinct animals are missing (Galetti et al. 2006, Kuprewicz 2013). Large mammals are among the animals most affected by defaunation. Ecological interactions between mammal and plant populations shape the vegetation dynamics through herbivory and physical damage (Keuroghlian \& Eaton 2009, Beck et al. 2013), and also through their role as seed dispersers and predators (Galetti et al. 2006, Andreazzi et al. 2009, Kuprewicz 2013).

In Rio de Janeiro state, several mammal surveys found a high richness of small and medium species and the local extinction of large herbivores as Tapirus terrestris (Linnaeus, 1758), feeding guild specialists as Priodontes maximus (Kerr, 1792), Myrmecophaga tridactyla (Linnaeus, 1758) and top predators as Panthera onca (Linnaeus, 1758) (Araújo et al. 2008, Modesto et al. 2008a, 2008b, Pessôa et al. 2009, Delciellos et al. 2012, Carvalho et al. 2014, Aximoff et al. 2015). As a result of these impacts many populations show low densities and changes in behavior and activity patterns (Di Bitetti et al. 2008, Galetti et al. 2016). In most cases the Atlantic Forest mammal surveys are conducted with combined use of more than one sampling technique, such as camera traps surveys, interviews, linear transects and search by tracks and signs (Modesto et al. 2008a, 2008b, Silva \& Passamani 2009, Espartosa et al. 2011, Delciellos et al. 2012, Carvalho et al. 2014). Most Atlantic Forest remnants are concentrated in the southeast region of Brazil, mainly in mountain hilltops of Serra do Mar. This mountain range cross the metropolitan zone of Rio de Janeiro in the "Baixada Fluminense" region (Custódio 2007), and this is the major refuge for wildlife in the surroundings of Rio de Janeiro city (MMA/IBAMA 2006). The Tinguá Biological Reserve is located in a megadiverse region of the Atlantic Forest. It has high plant diversity and richness (IPJB/UFRRJ 2002) and is equally important for the conservation of threatened and endemic species of birds, reptiles and amphibians (MMA/IBAMA 2006). For example, the Tinguá Biological Reserve is the only government-owned protected area in whole state of Rio de Janeiro where the Ornate Hawk-Eagle Spizaetus ornatus (Daudin, 1800) still occurs (Mendonça-Lima \& Pacheco 2003). Although mammalian surveys performed at Tinguá neighboring protected areas showed high richness and the presence of endemic and endangered species (Cunha 2007, Olifiers et al. 2007, Carvalho et al. 2014), the composition of mammal species of Tinguá Biological Reserve remains poorly known.

The goal of this paper was to show what is known about the current and historical richness and composition of Tinguá's assemblage of terrestrial mammals. For this objective we performed an intensive field survey by linear transects. In a complementary way, we performed nonstandard sampling following trails, literature search, surveys in museum collection and gathered informal reports. These reports, about rare and shy species, were obtained with former poachers, local residents, rangers and other employees. Based on this information we recorded the degree of threat and discussed the importance of TBR to Atlantic Forest Mammals conservation and the necessity of long-term mammal surveys.

\section{Materials and Methods}

\section{Study area}

The Tinguá Biological Reserve (22 $28^{\prime}$ 'S and $22^{\circ} 40^{\prime} \mathrm{S}, 43^{\circ} 36^{\prime} \mathrm{W}$ and $43^{\circ} 13^{\prime} \mathrm{W}$ ) (thereafter TBR) is the oldest protected area in Brazil; in 1833 emperor D. Pedro II created a Protection Forest to preserve the quality of the headwaters of three rivers, thus setting aside the area that later became TBR. Currently, TBR is administrated by "Chico Mendes Institute of Biodiversity Conservation” (ICMBio) - a government institute subordinate to the Ministry of the Environment. It is also the largest Biological Reserve in Rio de Janeiro state, with $248 \mathrm{~km}^{2}$ spread over valleys and hills of Serra do Mar up to the altitude of $1600 \mathrm{~m}$. The predominant vegetation is Dense Evergreen Atlantic Forest with a mix of mature and medium successional stages, and a canopy that reaches up to 25 meters. It has a high floristic diversity and the structure of the vegetation is considered one of the most well preserved in the whole Atlantic Forest biome (Iguatemy et al. 2017). The high terrain slope has prevented intensive logging. The east portion of TBR receives the rains that come from Atlantic Ocean. The mean annual temperature ranges between 20 and $26^{\circ} \mathrm{C}$ and the annual precipitation is about 2000 mm (1970-1990); there is no dry season (MMA/IBAMA 2006). The TBR is the core zone of a Biosphere Reserve of UNESCO, and close to other protected areas, like Araras Biological Reserve $\left(38 \mathrm{~km}^{2}\right)$, the Serra dos Órgãos National Park $\left(200 \mathrm{~km}^{2}\right)$ and Três Picos State Park $\left(587 \mathrm{~km}^{2}\right)$. This mosaic cover a total range of about $1.065 \mathrm{~km}^{2}$ (MMA/IBAMA 2006).

Despite its high biological value - preliminary surveys has revealed that TBR harbors 350 species of birds and 52 species of amphibians (IBAMA 1996, MMA/IBAMA 2000) - TBR is subject to several anthropic impacts. Poaching and harvest of palm heart are frequent in the Reserve, due to its large perimeter and poor fiscalization (MMA/ IBAMA 2006). Livestook and horses from vicinity also invade the area occasionally and the reserve is crossed by electrical transmission lines and an oil pipeline (MMA/IBAMA 2006). During the last twelve years, the TBR buffer zone was subject of some deforestation due to logistic projects and other enterprises (Fundação S.O.S Mata Atlântica \& INPA 2009, 2010, 2017).

\section{Data collection}

Between June 2005 and November 2006 a field survey was conducted using 10 linear transects spread throughout TBR forest. The length of transects ranged from $0.55 \mathrm{~km}$ to $2 \mathrm{~km}$ (average $=1.16 \mathrm{~km}$; sd= $0.46 \mathrm{~km}$ ) and the predominant vegetation was forests in late secondary successional stage. We started transect surveys from 30 minutes to one hour before sunrise and finished 3 or 4 hour after sunset. Transects were surveyed by one observer, rarely two, walking at $1 \mathrm{~km} / \mathrm{h}$, with brief stops each 50 or 100 meters. Besides that, opportunistic sightings and footprints were recorded from 2005 to 2009 , either during the fieldwork carried out for this study or other field activities that together summed $1060 \mathrm{~h}$. In the same period, we also recorded informal reports about 
the presence of medium or large mammals, cryptic or rare species with seventeen people that have a wide knowledge about the region, including former poachers, local residents that are in the region for over 20 years, TBR staff and researchers. During the study period, authorizations for research activities, which did not require catches for collections, were granted directly by the unit manager.

The mammal collection of the Museu Nacional at Rio de Janeiro was consulted in 2009 to record the species collected in the municipalities that harbor TBR (Nova Iguaçu, Duque de Caxias, Petrópolis and Miguel Pereira). A list of the specimens, summarizing all their information, was provided by the curators Dr. João A. Oliveira and Mr. Sérgio Maia Vaz. Only the specimens that were accurately identified in the list and do not have doubts about their identification were considered.

A literature search was conducted in specialized websites (e.g. Google Acadêmico, Scielo, Web of Science) aiming to compile faunistic surveys published up to 2016. To carry out the research we used key words "tinguá biological reserve", "mammals + reserva biológica do tinguá" or "reserva biológica do tinguá".

For each species we recorded the degree of threat using Bergallo et al. (2000) for the state of Rio de Janeiro, Chiarello et al. (2008) for the Brazil and the International Union for Conservation of Nature (IUCN 2015) for globally threatened species.

\section{Results}

A total of 433 kilometers walked on linear transects, $327 \mathrm{~km}$ diurnal and $106 \mathrm{~km}$ nocturnal, resulted in the visual records of 24 species of non-volant mammals. Occasional sightings and footprints recorded 22 species, adding ten species for those recorded through linear transects (Table 1). Three species were registered exclusively through reports, the neotropical otter Lontra longicaudis (Olfers, 1818), observed recently and the southern muriqui Brachyteles arachnoides (É. Geoffroy, 1806) and the jaguar Panthera onca (Linnaeus, 1758), recorded for the last time in the 1990s.

Thirty-seven species were recorded through surveys of specimens deposited in the Museu Nacional do Rio de Janeiro, mostly small mammals (Table 1). Twelve species recorded exclusively in the museum collection were Gracilinanus microtarsus (Wagner, 1842), Marmosops incanus (Lund, 1840) Marmosa paraguayanus (Tate, 1931) Leontopithecus rosalia (Linnaeus, 1766), Akodon serrensis Thomas, 1902, Calomys sp. Waterhouse, 1837, Euryoryzomys sp. Weksler, Percequillo \& Voss, 2006, Necromys lasiurus (Lund, 1841), Oligoryzomys sp. Bangs, 1900, Euryzygomatomys spinosus (G. Fisher, 1814) and the exotic species Rattus rattus (Linnaeus, 1758) and Rattus norvegicus (Berkenhout, 1769).

The literature review recorded 63 species (Vaz 1984, Tribe, 1987, Plano de Manejo 2006, Dias \& Peracchi 2007, Dias et al. 2008, Dias \& Peracchi 2008, Moratelli et al. 2011, Lourenço et al. 2014), 35 of non-volant mammals and 28 of bats (Table 1).

Summing up all kind of records 85 mammal species were registered, distributed in nine orders and 27 families. The orders that most contributed to species richness were Chiroptera with 28 species $(33 \%)$, Rodentia with 19 species (22\%) and Carnivora with 15 species (16.6\%). Didelphimorphia contributed with 9 species (10\%), Primates with five species $(6 \%)$, Artiodactyla and Cingulata with three each (3.5\%), Pilosa with two species (2.3\%) and Lagomorpha with one species (1.2\%). Five species were exotic: Felis catus, Canis lupus familiaris, Rattus rattus, Rattus norvergicus and Callithrix jacchus.

The total of mammals recorded in TBR corresponds to approximately $50 \%$ of the native terrestrial mammal species of the Rio de Janeiro state (Rocha et al. 2004), 27\% of Atlantic Forest mammals and 13\% of the endemic ones (Paglia et al. 2012). Twelve species (15\%) recorded in TBR are in some threat categories at state level (Bergallo et al. 2000), seven species (9\%) at national level (MMA 2014) and two species $(2.6 \%)$ are in some threat categories of IUCN (IUCN 2017) (Table 1).

\section{Discussion}

This study reports the first comprehensive list of the mammals of the region of Tinguá Biological Reserve, providing the most complete "picture" of what we know about TBR's mammals. Despite the widespread defaunation scenery of Atlantic forest (Canale et al. 2012, Galetti et al. 2016), the TBR still harbor populations of large frugivores and apex predators like brocket deer, white lipped peccary and cougar, besides several mesopredators. TBR is one of the last shelters for large mammals in Rio de Janeiro and the last one in the northern portion of the Serra do Mar ecoregion. For example, TBR is the only refuge for white-lipped peccaries from the central region of the state up to the extreme north. No protected area north of TBR has currents sightings of the species in recent years (Araújo et al. 2008, Modesto et al. 2008a, 2008b, Pessôa et al. 2009, Carvalho et al. 2014). The red-brocket deer, by its turn, was recorded by one opportunistic sighting and three reports, one with a photo of an individual slaughtered inside the TBR (Figure 1). According to Duarte et al. (2016) Rio de Janeiro state is out of the geographic distribution of the species but our results together with the records in the Parque Nacional da Serra da Bocaina (Delciellos et al., 2012), Parque Nacional do Itatiaia (Aximoff et al. 2015) and Reserva Biológica Poço das Antas (Araújo et al., 2008) suggest that this interpretation should be revised.

The TBR is the second one in number of mammals already recorded in "Serra do Mar" ecoregion of Atlantic Forest and in Rio de Janeiro state, with 80 native species, exceeded only by Itatiaia National Park, and followed by Serra dos Órgãos National Park, with 106 and 75 species respectively (Table 2). However, these two protected areas are among the best sampled in Rio de Janeiro (e.g. Schirch 1932, Ávila-Pires \& Gouveia 1977, Tribe 1987, Geise et al. 2004, Loretto \& Rajão 2005, Cunha 2007, Macedo et al. 2007, Olifiers et al. 2007), so an increase in the sampling effort could reveal an even more important role for TBR. Small mammals, for example, are clearly underrepresented, as there is only one previous surveys carried out by Vaz (1984). The number of rodent species can be considered low when compared with other Serra do Mar study areas (Geise et al. 2004, Olifiers et al. 2007). Studies focused on these groups and the use of other methodologies not used in this study and able to detect inconspicuous species, like pit-falls and camera-traps (e.g. Srbek-Araujo \& Chiarello 2005, Pardini \& Umetsu 2006), could increase the number of species and are strongly recommended.

For bats, the studies carried out by Dias \& Peracchi (2008) and Lourenço et al. (2014) resulted in a number of species similar to other localities (Table 2). However, the absence of records of species present in other areas of Rio de Janeiro's Atlantic Forest (eg. Chrotopterus auritus, Trachops cirrohsus and Noctilio leporinus) also suggests that TBR is undersampled and that other species can be recorded with 
Travassos, L. et al.

Table 1. Mammals recorded to the Tinguá Biological Reserve or around them, Rio de Janeiro state. The types of records were sighting in transection (T), opportunistic sighting $(\mathrm{O})$, footprints $(\mathrm{F})$, recorded in literature $(\mathrm{L})$, museum collection $(\mathrm{M})$ and report $(\mathrm{R})$. For species registered only by reports the year in which the species was observed is provided in parentheses. Classification in categories of threatened species are according to Bergallo et al.(2000) at state level, Environment Ministry list (2014) at national level and IUCN (2015) at world level. Codes of threat degree are DD (deficient data), LC (least concern), PT (presumably threatened), NT (near threatened), VU (vulnerable), EN (endangered), CR (critically endangered), PEX (probably extinct) and EX (extinct). Species assigned with an asterisk are endemic of the Atlantic Forest. For species at the museum collection, the number of the considered exemplars are provided at the end of the table.

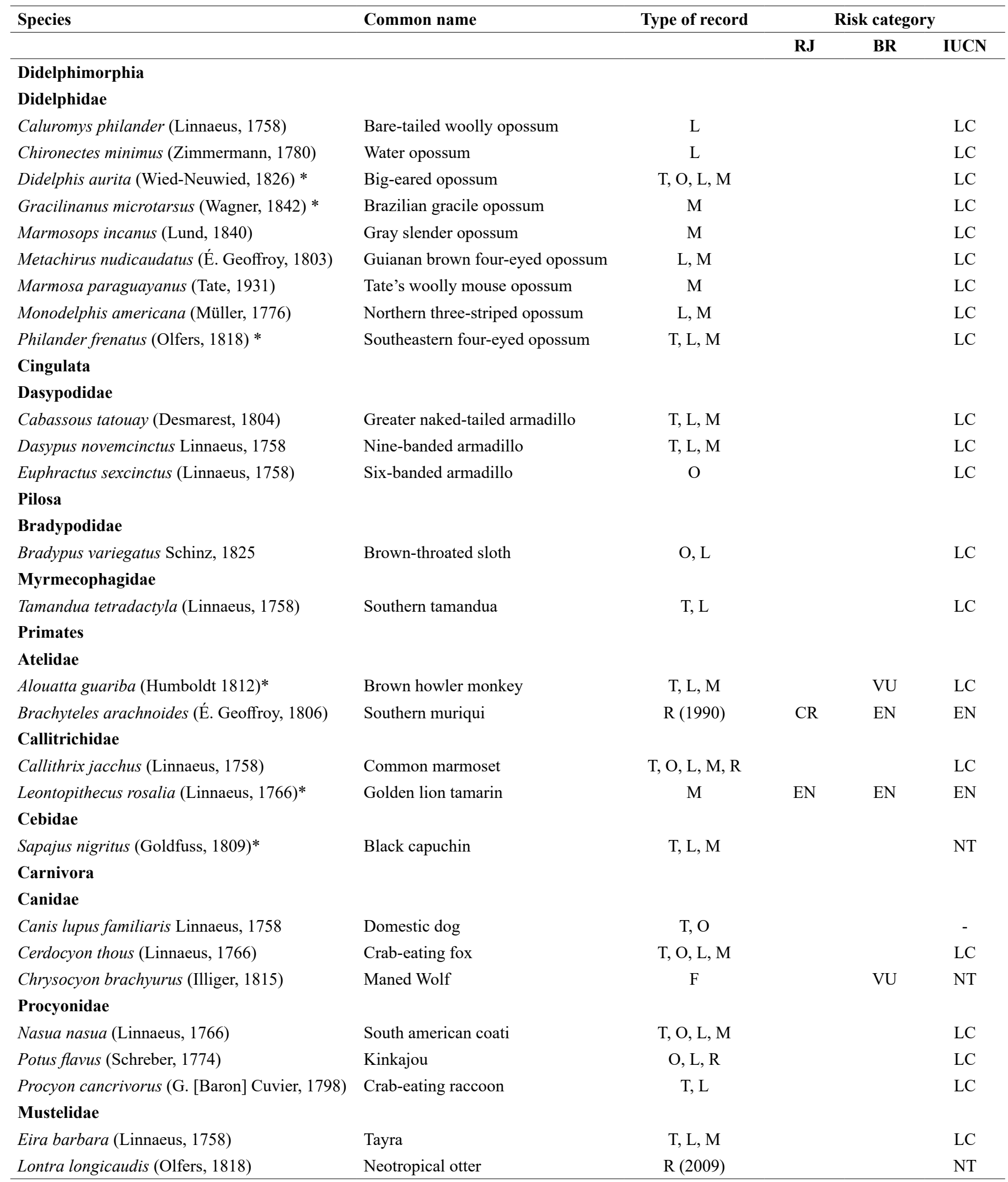


Continued Table 1.

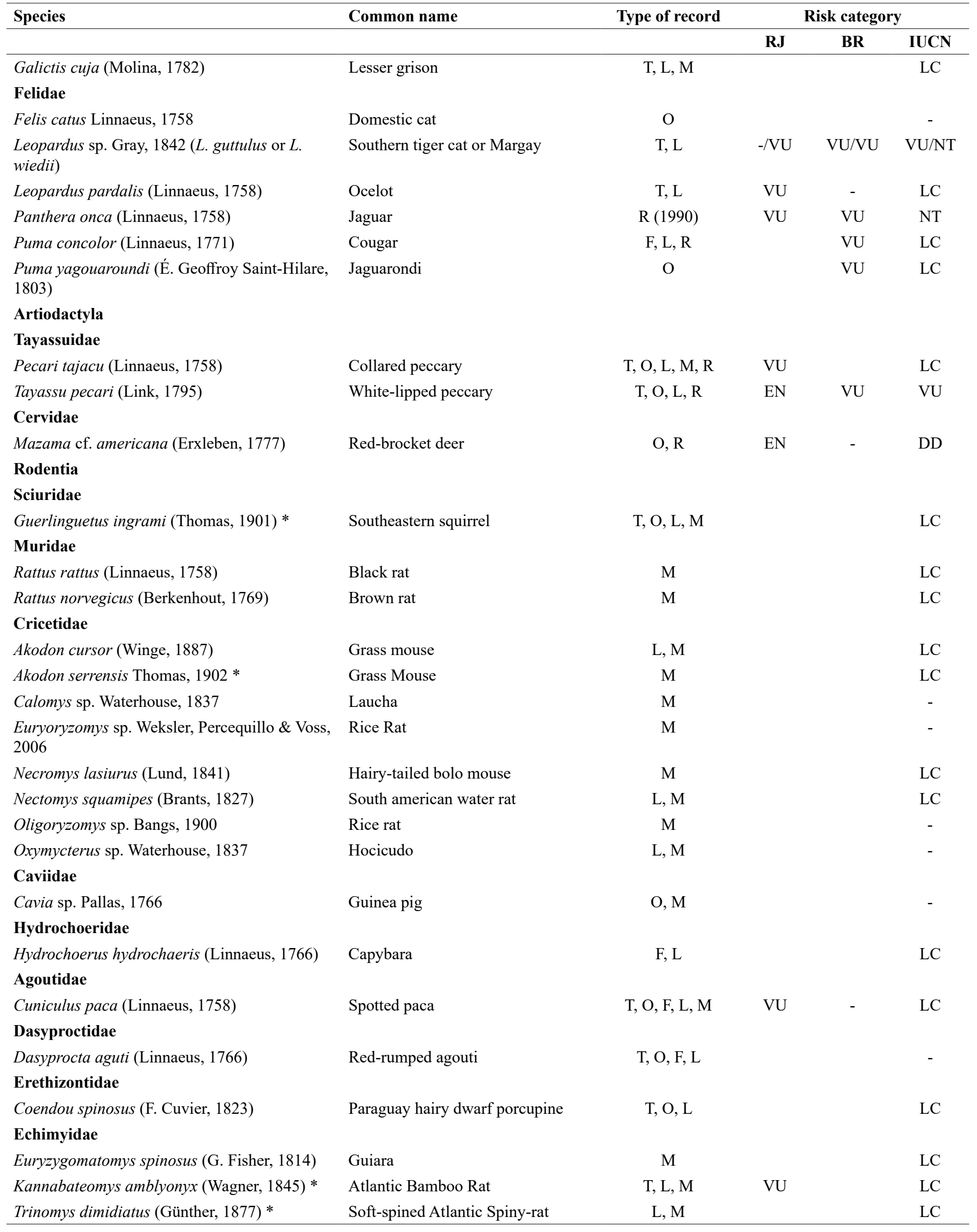


Continued Table 1.

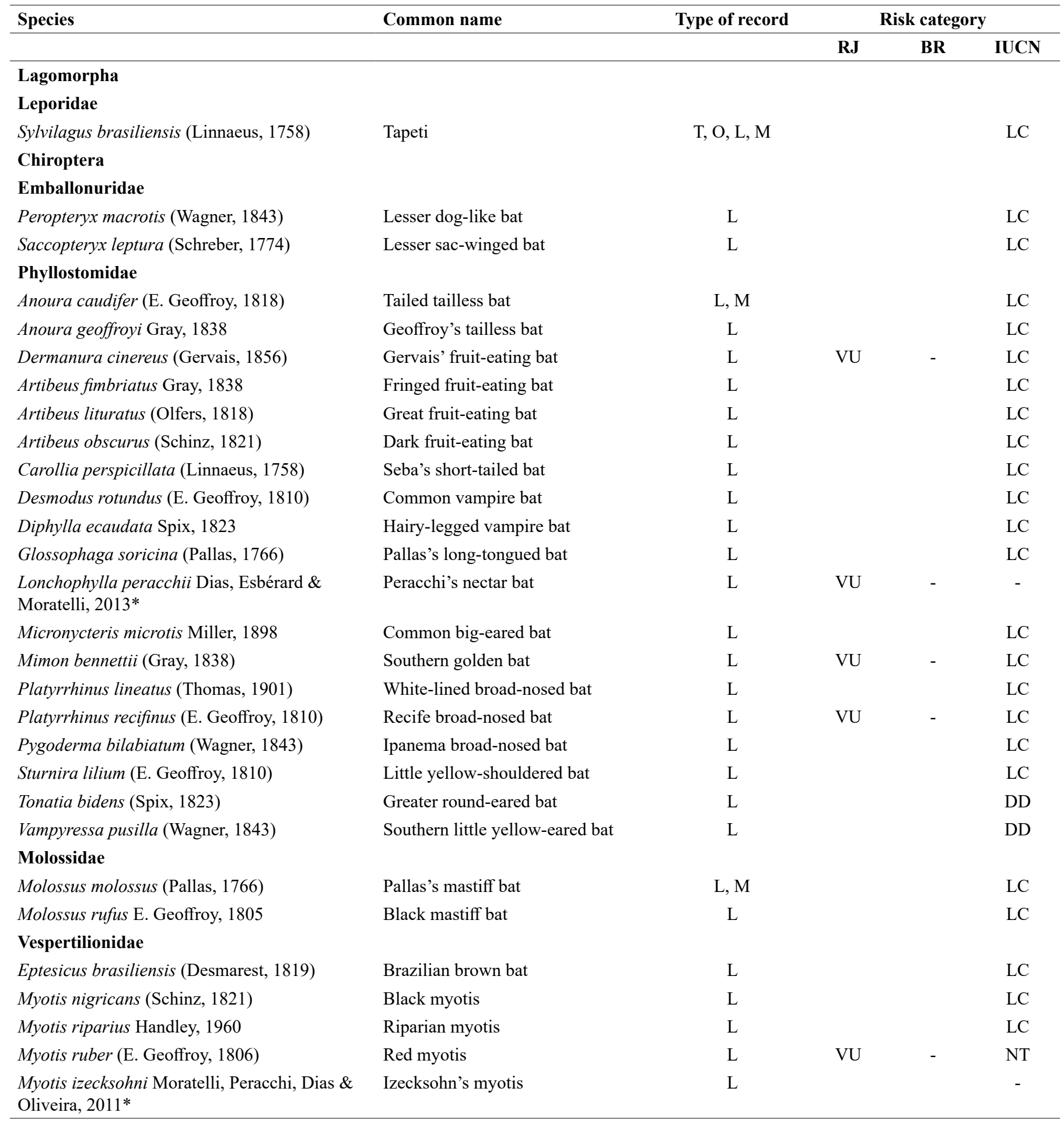

*Da: MN 5857, 5794, 5797, 5795, 5792, 5861, 5862, 5856, 5860, 5859, 5858, 5855, 5863, 5864, 5812, 5796, 5793, 5808, 5813, 5811, 42826, 50638, 51877, $51873,51877,51878,28895,28825,28835,28841,5799,5798,5801,5800,28913,50672 ; G m:$ MN 53886; Mi: MN 27826; Mn: MN 5805, 5806; Mp: MN 28594, 42823, 50639, 51876; Ma: MN 10209; Pf: MN 50653, 5807, 5804, 5802, 25610, 25308, 25018, 27100, 25017, 26628, 8235, 1203; Ct: MN 1854; Dn: MN 1853, 2432, 2433, 10044, 10070, 10073,10079; Ag: MN: 30474; Cj: MN 30492; Lr: MN 1834; Sn; 31859; Ct: MN 25596; Nn: MN 3059, 3060, 5835, 8482; Eb: MN 7309; Gc: MN 5809, 29985; Pt: MN -; Gi: MN 30491; Rr: MN 30512, 52419, 52420, 52421, 53309, 53310, 53311, 53312, 53313, 53314; Rn: MN 42827, 59421; Ac: MN 2225, 5827, 5822, 5823, 26792, 25741, 26810, 28928, 30726, 30730; As: MN 51664; Calomys sp.: MN 60536; E sp.: MN 5824; Nl: MN 25029; Ns: MN 5826, 6468, 28542, 28840, 28844, 28955, 28991, 30129, 30142, 42827, 42828, 42829, 61792, 61793, 61794, 61795, 61991; Oligoryzomys sp.: MN 50723, 53887; Oxymycterus sp.: MN 2226, 5814, 5825, 26854, 28553, 28829, 30135, 30138, 42824; Cavia sp.: MN 43273; Cp: MN 50400; Es: MN 50721, 53885; Ka: MN 61811; Td: MN 4941, 4942, 4943, 4944, 4945, 4946, 4947, 4948, 4949, 4950, 4951, 4953, 4954, 8302, 21098, 34488; Sb: MN 2436, 24068, 50704; Ac: MN 43084, 43269, 43305; Mm: MN 47138, 50084, 50085 . 

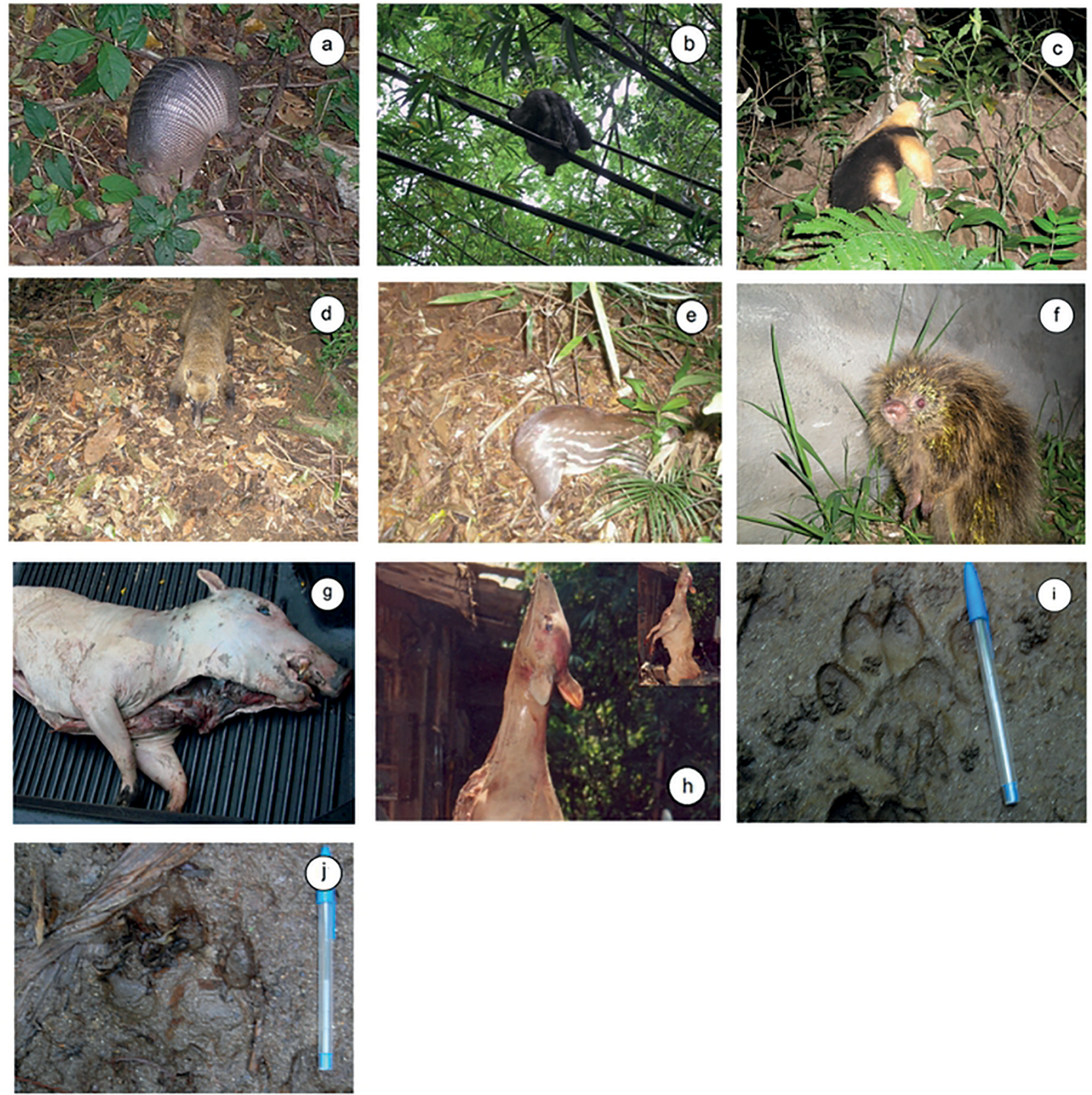

Figure 1. Some of medium and large-sized mammals of Tinguá Biological Reserve, Rio de Janeiro, Brazil. a) Nine-banded armadillo (Dasypus novemcinctus); b) Brown-throated sloth (Bradypus variegatus); c) Southern tamandua (Tamandua tetradactyla); d) South american coati (Nasua nasua); e) paca (Cuniculus paca); f) Paraguay hairy dwarf porcupine (Coendou spinosus); g) white-lipped-peccari (Tayassu pecari) shot by poachers and seized by federal police; h) Red-brocket deer (Mazama cf. americana) hunted in Tinguá Biological Reserve; i) Footprint of maned wolf(Chrysocyon brachyurus); j) Footprint of cougar (Puma concolor).

adequate sampling effort. In recent years, two new species of bats were assigned in TRB (Moratelli et al. 2011, Dias et al. 2013). Lonchophylla peracchii was described from specimens that had been first identified as L. bokermanni (Dias et al. 2013). Myotis izecksohni, previously identified as M. levis, had their types collected in TRB (Moratelli et al. 2011). This fact suggests that other new species can be hidden under cryptic taxa, reinforcing the importance of taxonomic studies.
Two species recorded by reports were no longer seen at TBR. The southern muriqui Brachyteles arachnoides (É. Geoffroy, 1806) was recorded in 1979 by an amateur ornithologist, Romildo de Mello, by a former poacher in the 1980s and by one of the authors in the 1990s, but its currently presence in TBR requires confirmation. The literature confirms the occurrence of the jaguar Panthera onca in Tinguá region in late 1960 decade (Silveira 1968) and we obtained two reports by former 
Travassos, L. et al.

Table 2. Inventories of mammals in Ombrofilous Dense Atlantic Rainforest and Semideciduous and their respective areas of study. Medium mammals included Cavia, Guerlinguetus and Didelphis.

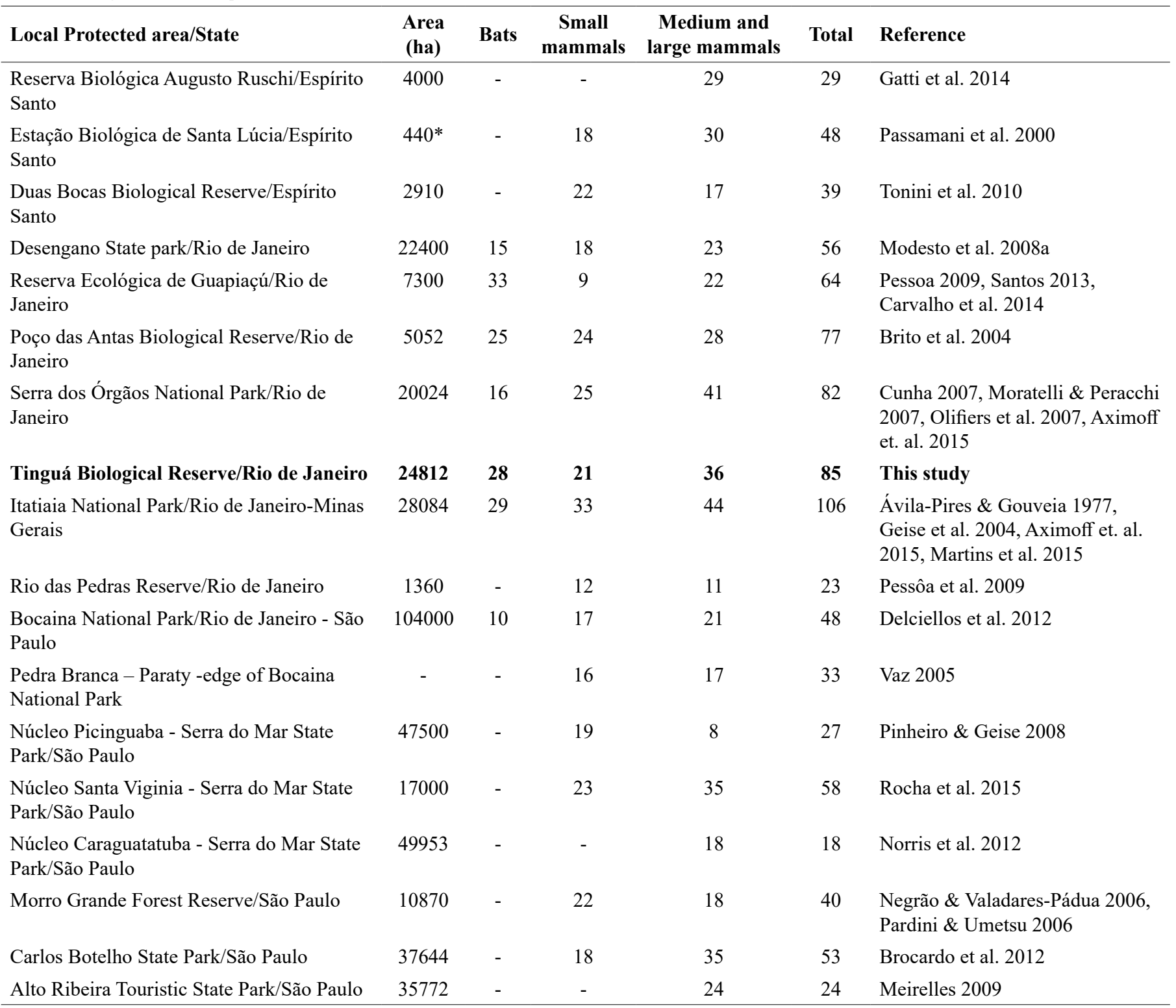

poachers that described the killing of two individuals, an young male (whose carcass weighed approximately $30 \mathrm{~kg}$ ) in the early $1980 \mathrm{~s}$ and one adult in the early 1990s. The loss and fragmentation of the habitat and hunting pressure (and competition with human hunters by the same prey species) can have extinguished the jaguars in TBR.

Another species previously recorded in the museum collection and not found nowadays was the golden-lion-tamarin Leontopithecus rosalia Linnaeus, 1766. The species was collected in Duque de Caxias municipality, locality of "Serra do Barro Branco" in 1939, near the area that would later become TBR. This record suggests that the lower slopes of TBR once housed a L. rosalia population, confirming the distribution of this species in the "Baixada Fluminense" (Coimbra-Filho 1969). This locality is in the same mountain range where a group of the species was recorded recently (Burity et al. 2007).
Some species which potential distribution includes the TBR and were never recorded in the area were the bush dog Speothos venaticus (Lund, 1842), a specialist carnivore, and large Insectivores and frugivores like Myrmecophaga tridactyla (Linnaeus, 1758) and Tapirus terrestris (Linnaeus, 1758) respectively. Although there are scarce records of lowland tapirs in Rio de Janeiro state (Schirch 1932, Ávila-Pires \& Gouveia 1977, Spix \& Martius 1981), the habitat of TBR is very similar of contiguous Serra dos Órgãos where the species was seen by early naturalists (Schirch 1932, Spix \& Martius 1981). Therefore, it seems that these species are also locally extinct at TBR.

We also did not record medium and small species that have potential distribution for this portion of Serra do Mar including the nine-banded armadillo Dasypus septemcinctus, the marmoset Callithrix aurita, the titi monkey Callicebus nigrifrons, small rodents (Phylomys, Dellomys, 
Juliomys, Thaptomys) and some bats (Chrotopterus auritus, Trachops cirrohsus and Noctilio leporinus) among others species. These absences can be a methodological artifact, because few studies were long-term and some TRB areas, especially the most inaccessible stretches, were never sampled. However, the arrival of exotic invasive species can be an alternative explanation for the absence of some of them. Rattus rattus and Rattus norvergicus, for example, were reported in TRB for the first time in the 1940s. These rodents are effective competitors with small native rodents and can even prey upon some of them (e.g. Banks \& Hughes 2012). Calithrix jacchus, by its turn, can also have negative impacts in other primate populations (e.g. Ruiz-Miranda et al. 2006). Besides these species, this study report for the first time the presence of Felis catus and Canis lupus familiaris within TBR. These animals, by their turn, have negative impacts on mammal population within protected areas (Galetti \& Sazima 2006, Lessa et al. 2016).

Inversely, the unexpected presence of the maned-wolf Chrysocyon brachyurus Illiger, 1815 was first documented in TBR. This species is typical from the cerrado but has been recorded in areas previously occupied by humid forests in the southeast coastal region (Queirolo et al. 2011). The process of savanization of the Atlantic Forest can be an important factor for the range expansion of this species (Sampaio et al. 2017).

The field sampling carried out in this study was useful to update the first TBR mammal list and show that species recorded by Vaz (1984) are still there. In comparison with other surveys in Atlantic Forest reserves (Cunha 2007, Norris et al. 2012, Rocha-Mendes et al. 2015), linear transects in TBR recorded more species of meso-predators. Besides the conservation status of the area, the record of many species of medium carnivores could be due to the use of local field workers, who are highly familiar with the forest and its local fauna, perceiving the signs of them easily, including the most inconspicuous ones.

In summary, our results show that TBR still maintains a high richness of mammals, and it is an important remnant to conserve medium and large-sized Atlantic Forest mammals. This patch was able to conserve populations of large game species like white lipped peccaries and can be a source of individuals to recolonize other areas, naturally or through reintroduction initiatives. It can also receive reintroduction initiatives provided that hunting pressure is controlled. Mammalogists and mammal ecologists have much work ahead, with low logistical investment due to its proximity to the large urban centers. Considering that hunting is still a significant presence in TBR interior, we recommend that population estimates of large mammals be produced and poaching effects investigated. The sampling of less studied groups such as Rodentia, Chiroptera, and Didelphimorphia would also be desirable. Most studies have been performed around a dirt road that cuts the TBR, while more remote areas remain without any sampling. The sampling of these areas and the use of the pitfalls, camera-traps and live-traps along all the altitudinal gradient, with appropriate sampling effort, could increase the number of species for the Reserve. All these efforts to know TBR species, however, will not be worth if the area continues to be neglected by the high levels of administration of protected areas in Brazil. Besides hunting, internal fragmentation and exotic species, TBR is threatened by the urban growth around it and the pressure to reduce its area and its protection level. If nothing is done to contain these threats, one of the best representatives of what was the mastofauna of the Atlantic Forest in the state of Rio de Janeiro may become just another example of an empty forest.

\section{Acknowledgments}

We are very grateful to Eduardo Bernhardt, Gustavo Borges, Adilson Salino, Nery Pinto and "Seu" Walter, by help us in hard field work. Special thanks to Dr. João A. Oliveira, Mr. Sérgio Maia Vaz and Ms. Stella Maris Franco, by assistance to access the mammalian collection of Museu Nacional do Rio de Janeiro/UFRJ. We are very grateful to Instituto Chico Mendes de Conservação da Biodiversidade by logistic support by Mr. Márcio de Castro das Mercês (Agent of TBR) and, Mr. Luis Henrique dos Santos Teixeira (Director of TBR). We thank Conservation International - CEPF (Critical Ecosystem Partnership Fund) by financial support and Jason Cole and Ivana Lamas. We also thank Coordenação de Aperfeiçoamento de Pessoal de Nivel Superior (CAPES), Dr. Beatriz Beisiegel and Bsc. Rogério Cunha de Paula for identifying a maned wolf footprint, Dr. José Maurício Barbanti Duarte for photographic identification of a Mazama. To Carlos Eduardo de Viveiros Grelle, Adrian Monjeau and an anonymous reviewer for the useful comments in earlier versions of this manuscript.

\section{Authors' Contributions}

Leandro Travassos: Contribution to data collection; contribution to data analysis and interpretation; contribution to manuscript preparation. Israel Dias Carvalho: Contribution to data collection.

Alexandra S. Pires: Contribution to data analysis and interpretation; contribution to critical revision, adding intellectual content.

Sérgio Nunes Gonçalves: Contribution to data collection.

Paulo Malvino Oliveira: Contribution to data collection.

Alexandre Saraiva: Contribution to data collection.

Fernando A. S. Fernandez: Contribution to critical revision, adding intellectual content.

\section{Conflicts of interest}

The authors declare that they have no conflict of interest related to the publication of this manuscript.

\section{References}

ANDREAZZI, C.S., PIRES, A.S. \& FERNANDEZ, F.A.S. 2009. Mamíferos e palmeiras neotropicais: interações em paisagens fragmentadas. Oecol. Bras. 13(4): 554-574.

ARAÚJO, R.M., SOUZA, M.B. \& RUIZ-MIRANDA, C.R. 2008. Densidade e tamanho populacional de mamíferos cinegéticos em duas Unidades de Conservação do Estado do Rio de Janeiro, Brasil. Iheringia, Sér. Zool. 98(3): 391-396

ÁVILA-PIRES, F.D. \& GOUVÊA, E. 1977. Mamíferos do Parque Nacional do Itatiaia. Bol. Mus. Nac. 291: 1-29.

AXIMOFF, I., CRONEMBERGER, C. \& PEREIRA, F.A. 2015. Amostragem de longa duração por armadilhas fotográficas dos mamíferos terrestres em dois parques nacionais no estado do Rio de Janeiro. Oecol. Aust. 19(1): 215-231.

BANKS, P.B. \& HUGHES, N. K. 2012. A review of the evidence for potential impacts of black rats (Rattus rattus) on wildlife and humans in Australia. Wild. Res. 39: 78-88. 
BECK, H., SNODGRASS, J.W. \& THEBPANYA, P. 2013. Long-term exclosure of large terrestrial vertebrates: implications of defaunation for seedling demographics in the Amazon rainforest. Biol. Conserv. 163: 115-121.

BERGALLO, H.G., FIDALGO, E.C.C., ROCHA, C.F.D., UZÊDA, M.C., COSTA, M.B. ALVES, M.A.S., VAN SLUYS, M., SANTOS, M.A., COSTA, T.C.C. \& COZZOLINO, A.C.R. (Orgs.). Estratégias e Ações para a Conservação da Biodiversidade no Estado do Rio de Janeiro. Instituto Biomas. Rio de Janeiro.

BERGALlO, H.G., GEISE, L., BONVICINO, C.R., CERQUEIRA, R., D'ANDREA, P.S. ESBÉRARD, C.E., FERNANDEZ, F.A.S., GRELLE, C.E., PERACCHI, A. L., SICILIANO, S. \& VAZ, S.M. 2000. Mamíferos; pp. 125-135, in: BERGALLO, H.G., ROCHA, C.F.D., ALVES, M.A.S. \& VAN SLUYS, M. (eds.). A fauna ameaçada de extinção do estado do Rio de Janeiro. Editora da Universidade do Estado do Rio de Janeiro. Rio de Janeiro.

BONVICINO, C.R, OLIVEIRA, J. A. \& D'ANDREA, P.S. 2008. Guia dos Roedores do Brasil., com chaves para gêneros baseadas em caracteres externos. Série de Manuais Técnicos 11. Centro Pan-Americano de Febre Aftosa - OPAS/OMS.

BROCADO, C.R., RODARTE, R., BUENO, R.S., CULOT, L. \& GALETTI, M. Non-volant mammals of Carlos Botelho State Park, Paranapiacaba Forest Continuum. 2012. Biota Neotrop. 12(4): 1-11 http//www.biotaneotropica. org.br $/ \mathrm{v} 12 \mathrm{n} 4$ ptabstract?inventory+bn02512042012 (last access at 18/september2017)

BRITO, D., OLIVEIRA, L.C., \& MELLO, M.A.R. 2004. An overview of mammalian conservation at Poço das Antas Biological Reserve, southeastern Brazil. J. Nat. Conserv. 12 (2004) 219-228.

BURITY, C.H.F., CRUZ, L.D., ROCHA, V.L., CONCEIÇÃO, N.B., LUZ, D.E., SANTOS, D.S., CAMPOS, D.C., \& PISSINATI, A. 2007. Golden Lion Tamarins, Leontopithecus rosalia (Linnaeus, 1766) in the Taquara Municipal Natural Park (Duque de Caxias, RJ): A Southern Extension of the known Range. Neotrop. Primates 14(1): 30-31.

CANALE, G.R, PERES, C.A, GUIDORIZZI, C.E., GATTO, C.A.F., \& KIERULFF, M.C.M. 2012. Pervasive Defaunation of Forest Remnants in a Tropical Biodiversity Hotspot. PLoSONE 7(8): e41671.

CARVALHO, I.D., OLIVEIRA, R., \& PIRES, A.S. 2014. Medium and largesized mammals of the Reserva Ecológica de Guapiaçú, Cachoeiras de Macacu, RJ. Biota Neotrop. 14(3): 1-9. http://dx.doi.org/10.1590/167606032014007414 (last access at 18september/2017)

CHIARELLO, A.G. 1999. Effects of fragmentation of the Atlantic forest on mammal communities in south-eastern Brazil. Biol. Conserv. 89:71-82.

CHIARELLO, A.G. 2000. Influência da caça ilegal sobre mamíferos e aves das matas de tabuleiro do norte do estado Espírito Santo. Bol. Mus. Biol. Mello Leitão. 11/12: 379-396.

CHIARELlO, A.G., AGUIAR, L.M.S., CERQUEIRA, R., MELO, F.R., RODRIGUES, F.H.G. \& SILVA, V.M.F. 2008. Mamíferos ameaçados de extinção no Brasil; pp. 681-702. In: MACHADO, A.B.M., DRUMMOND, G.M. \& PAGLIA, A.P. (eds.) Livro vermelho da fauna brasileira ameaçada de extincão. MMA/Fundacão Biodiversitas. 1420p.

COIMBRA-FILHO, A.F. 2006. Apresentação. Rodriguésia 57(3).

COSTA, L.P., LEITE, Y.L.R. \& PATTON, J.L. 2003. Phylogeography and systematic notes on two species of gracile mouse opossums, genus Gracilinanus (Marsupialia: Didelphidae) from Brazil. Proc. Biol. Soc. Wash. 116(2):275-292.

CULLEN Jr., L.; BODMER, R.E. \& VALLADARES-PÁDUA, C. 2000. Effects of hunting in habitat fragments of the Atlantic Forests, Brazil. Biol. Conserv. 95:49-56.http://www.sciencedirect.com/science/article/pii/ S0006320700000112

CULLEN Jr., L.; BODMER, R.E. \& VALLADARES-PÁDUA, C. 2001. Ecological consequences of hunting in Atlantic forests patches, São Paulo, Brazil. Oryx, 35: 137-144.

CULLEN Jr., L.; BODMER, R.E.; VALLADARES-PÁDUA, C. \& BALLOU, J.D. 2004. Mammalian densities and species extinctions in atlantic forest fragments: The need for population management. Pp 211-226. In: Silvius, K.M., Bodmer, R.E. \& Fragoso, J.M.V. (eds.). People in Nature: Wildlife Conservation in South and Central America. Columbia University Press. New York.
CUNHA, A.A. 2007. Alterações na composição da comunidade e o status de conservação dos mamíferos de médio e grande porte da Serra dos Órgãos. In Ciência e conservação na Serra dos Órgãos (C. Cronemberger \& E.B. Viveiros de Castro, orgs) IBAMA, Brasília, p. 211-224.

CUSTÓDIO, I. A. 2007. História da Paisagem da Região de Tinguá e Arredores da Baía de Guanabara, Rio de Janeiro, RJ. Dissertação de mestrado. Instituto de Pesquisas Jardim Botânico/Escola Nacional de Botânica Tropical. Rio de Janeiro.

DEAN, W. 1996. A ferro e fogo: a história e a devastação da Mata Atlântica brasileira. Companhia das Letras. São Paulo.

DELCIELLOS, A.C., NOVAES, R.L.M., LOGUERCIO, M.F.C., GEISE, L., SANTORI, R.T., SOUZA, R.F., PAPI, B.S., RAICES, D., VIEIRA, N.R., FELIX, S., DETOGNE, N., SILVA, C.C.S., BERGALLO, H.G. \& ROCHABARBOSA, O. 2012. Mammals of Serra da Bocaina National Park, state of Rio de Janeiro, southeastern Brazil. Check List, 8(4): 675-692.

DIAS, D., ESBÉRARD, C.E.L. \& PERACCHI, A.L. 2008. Riqueza, diversidade de espécies e variação altitudinal de morcegos na Reserva Biológica do Tinguá, estado do Rio de Janeiro, Brasil (Mammalia, Chiroptera); pp. 125 142, in: REIS, N.R.; PERACCHI, A.L.; \& SANTOS, G.A.S.D. (Orgs.). Ecologia de morcegos. Technical Books. Londrina.

DIAS, D. \& PERACCHI, A.L. 2007. Primeiro registro de Myotis riparius Handley (Mammalia, Chiroptera, Vespertilionidae) no estado do Rio de Janeiro, sudeste do Brasil. Rev. Bras. Zool. 24 (2): 508-511.

DIAS, D., \& PERACCHI, A.L. 2008. Quirópteros da Reserva Biológica do Tinguá, estado do Rio de Janeiro, sudeste do Brasil (Mammalia: Chiroptera). Rev. Bras. Zool. 25(2): 333-369.

DIAS, D., ESBÉRARD, C.E.L. \& MORATELLI, R. 2013. A new species of Lonchophylla (Chiroptera, Phyllostomidae) from the Atlantic Forest of southeastern Brazil, with comments on L. bokermanni. Zootaxa 3722 (3): 347-360.

DI BITETTI, M.S., PAVIOLO, A., FERRARI, C.A., DE ANGELO, C., \& DI BLANCO, Y. 2008. Differential Responses to Hunting in Two Sympatric Species of Brocket Deer (Mazama americana and M. nana). Biotropica 40(5): 636-645.

DIRZO, R., YOUNG, H.S., GALETTI, M. CEBALLOS, G., ISAAC, N.J.B \& COLLEN, B. 2014. Defaunation in the Anthropocene. Science 345, 401 (2014); DOI: 10.1126/science.1251817

DUARTE, J.M.B \& VOGLIOTTI, A. 2016. Mazama americana. The IUCN Red List of ThreatenedSpecies2016:e.T29619A22154827. http://dx.doi. org/10.2305/IUCN.UK.20161.RLTS.T29619A22154827.en. (last access at 10july2017).

ESPARTOSA, K.D., PINOTTI, B.T. \& PARDINI, R. 2011.Performance of camera trapping and track counts for surveying large mammals in rainforest remnants. Biodivers. Conserv. 20: 2815-2829.

FERRAZ, G., RUSSEL, G.J.,STOUFFER,P.C.,BIERREGAARD,R.O.,PIMM,S.L. \&LOVEJOY,T.E., 2003. Rates of species loss fromAmazonian forest fragments. Proc. Natl. Acad. Sci. U.S.A. 100, 14069-14073.

FUNDAÇÃO S.O.S MATA ATLÂNTICA \& INSTITUTO NACIONAL DE PESQUISAS ESPACIAIS. 2009. Atlas dos remanescentes florestais da Mata Atlântica. Período 2005-2008. Relatório parcial. São Paulo.

FUNDAÇÃO S.O.S MATA ATLÂNTICA \& INSTITUTO NACIONAL DE PESQUISAS ESPACIAIS. 2010. Atlas dos remanescentes florestais da Mata Atlântica. Período 2008-2010. Dados parciais dos estados avaliados até maio de 2010. São Paulo.

FUNDAÇÃO S.O.S MATA ATLÂNTICA \& INSTITUTO NACIONAL DE PESQUISAS ESPACIAIS. 2017. Atlas dos remanescentes florestais da Mata Atlântica. Período 2016-2017. Relatório técnico. São Paulo.

GALETTI, M., DONATTI, C.I., PIRES, A.S., GUIMARÃES JR, P.R \& JORDANO, P. 2006. Seed survival and dispersal of endemic Atlantic Forest palm: the combined effects of defaunation and forest fragmentation. Bot. J. Linn. Soc. 151: 141-149. 
GALETTI, M., BROCARDO C.R., BEGOTTI, R.A., HORTENCI, L., ROCHA-MENDES, F., BERNARDO, C.S.S., BUENO, R.S., NOBRE, R., BOVENDORP, R.S., MARQUES, R. M., MEIRELLES, F., GOBBO, S. K., BECA, G., SCHMAEDECKE, G. \& SIQUEIRA, T. 2016. Defaunation and biomass collapse of mammals in the largest Atlantic forest remnant. Anim. Conserv. 1-12.

GATTI, A., SEGATTO, B., CARNELLI, C.C. \& MOREIRA, D.O. 2014 Mamíferos de médio e grande porte da Reserva Biológica Augusto Ruschi, Espírito Santo. Nat. on line. 12 (2): 61-68.

GEISE, L., PEREIRA, L.G., BOSSI, D.E.P. \& BERGALLO, H.G. 2004. Pattern of Elevational Distribution and Richness of Non Volant Mammals in Itatiaia National Park and its Surroundings in Southeastern Brazil. Braz. J. Biol. 64(3B): 599-612.

IGUATEMY, M.A.; SILVA NETO, S.J., LOBÃO, A., BOVINI, M.G., BRAGA, J.M.A., NEGREIROS, F.F., LIMA, H.C., RODRIGUES, P.J.F.P., SIMÕESJESUS, MARIELA F., HOTTZ, D., LIMA, M.S.C.; RAMOS, E., QUINET, A., SOUZA, M., PESSOA, S.V.A., KURTZ, B.C., BARROS, C.F. 2017. AN ANNOTATED CHECKLIST OF ATLANTIC RAINFOREST TREES IN SOUTHEASTERN BRAZIL, TINGUÁ BIOLOGICAL RESERVE, RIO DE JANEIRO. J. Bot. Res. Inst. Texas 11(2): 479 - 497.

INSTITUTO BRASILEIRO DO MEIOAMBIENTE E RECURSOS NATURAIS RENOVÁVEIS (IBAMA). 1996. Plano de Ação Emergencial - Reserva Biológica do Tinguá. Diretoria de Ecossistemas. Dpto de Unidades de Conservação. Brasília.

INTERNATIONAL UNION FOR CONCERVATION OF NATURE (IUCN). 2017. IUCN Red List of Threatened Species. Version 2017-1. http://www. iucnredlist.org. (last access at 16june2017).

JORGE, M.L.S., GALETTI, M., RIBEIRO, M.C. \& FERRAZ, K.M.P. 2013 Mammal defaunation as surrogate of trophic cascades in a biodiversity hotspot. Biol. Conserv. 163, 49-57.

KEUROGHLIAN, A. \& EATON, D.P. 2009. Removal of palm fruits and ecosystem engineering in palm stands by white-lipped peccaries (Tayassu pecari) and other frugivores in an isolated Atlantic Forest fragment Biodivers. Conserv. 18:1733-1750.

KUPREWICZ, E.K. 2013. Mammal abundances and seed traits control the seed dispersal and predation roles of terrestrial mammals in a Costa Rican Forest. Biotropica, 45(3): 333-342.

LAURANCE, W.F., LOVEJOY, T.E., VASCONCELOS, H.L., BRUNA, E.M., DIDHAM, R.K., STOUFFER, P.C., GASCON, C., BIERREGAARD, R.O., LAURANCE, S.G. \& SAMPAIO, E., 2002. Ecosystem decay of Amazonian forest fragments: a 22-year investigation. Conserv. Biol. 16, 605-618.

LESSA, I., GUIMARÃES, T.C.S., BERGALLO, H.G., A. CUNHA \& VIEIRA, E.M. 2016. Domestic dogs in protected areas: a threat to Brazilian mammals? Natureza \& Conservacão 14(2): 46-56.

LORETTO, D. \& RAJÃO, H. 2005. Novos registros de primatas no Parque Nacional do Itatiaia, com ênfase em Brachyteles arachnoides (Primates, Atelidae). Neotrop. Primates 13(2): 28-30.

LOURENÇO, E.C.; GOMES, L.A.C.; PINHEIRO, M.C.; PATRÍCIO, P.M.P.; FAMADAS, K.M. 2014. Composition of bat assemblages (Mammalia: Chiroptera) in tropical riparian forests. Zoologia, 31(4):361-369.

MACEDO, J., LORETTO, D., MELLO, M.C.S., FREITAS, S.R., VIEIRA, M.V. \& CERQUEIRA, R. 2007. História natural dos mamíferos de uma área perturbada do Parque Nacional da Serra dos Órgãos; pp. 165-181. In Ciência e conservação na Serra dos Órgãos (C. Cronemberger \& E.B. Viveiros de Castro, orgs) IBAMA, Brasília, p. 165-181.

MARTINS, M. A., CARVALHO, W. D. D., DIAS, D., FRANÇA, D. D. S., OLIVEIRA, M. B. D., \& PERACCHI, A. L. (2015). Bat species richness (Mammalia, Chiroptera) along an elevational gradient in the Atlantic Forest of Southeastern Brazil. Acta Chiropterol. 17(2), 401-409.

MEIRELLES F.A. 2009. Levantamento e censo de aves e mamíferos cinegéticos no Parque Estadual Turístico do Alto Ribeira (PETAR), SP. Trabalho de Conclusão de Curso, Universidade Estadual Paulista, Rio Claro.

MENDONCA-LIMA, A. \& J. F. PACHECO. 2003. Registros recentes de falconiformes na Reserva Biológica do Tinguá, RJ. Boletim ABFPAR 6 (1):7-9.
MINISTÉRIO DO MEIO AMBIENTE. 2000. Avaliação e ações prioritárias para a conservação da biodiversidade da Mata Atlântica e Campos Sulinos. Por: Conservation International do Brasil, Fundação SOS Mata Atlântica, Fundação Biodiversitas, Instituto de Pesquisas Ecológicas, Secretaria do Meio Ambiente do Estado de São Paulo, SEMAD/Instituto Estadual de Florestas-MG. Brasília: MMA/SBF. 40 pp.

MINISTERIO DO MEIO AMBIENTE. 2014. Portaria nº44 de 17 de dezembro de 2014. http://www.in.gov.br/autenticidade.html, 00012014121800121

MINISTÉRIO DO MEIO AMBIENTE/INSTITUTO BRASILEIRO DO MEIO AMBIENTE E DOS RECURSOS NATURAIS RENOVÁVEIS. 2006. Plano de Manejo da Reserva Biológica do Tinguá, Brasília. 102 pp.

MODESTO, T.C., PESSÔA, F.S., ENRICI, M.C., ATTIAS, N., JORDÃONOGUEIRA, T., COSTA, L.M., ALMEIDA, J., ALBUQUERQUE, H.G., \& BERGALLO, H.G. 2008a. Mamíferos do Parque Estadual do Desengano, Rio de Janeiro, Brasil. Biota Neotrop. 8(4): 153-159, http://dx.doi. org/10.1590/S1676-06032008000400015 (last access at 18september2017)

MODESTO, T.C., PESSÔA, F.S., JORDÃO-NOGUEIRA, T., ENRICI, M.C., COSTA, L.M., ATTIAS, N., ALMEIDA, J., RAICES,D.S.L., ALBUQUerQUe, H.G., PEREIRA, B.C., ESBÉRARD, C.E.L. \& BERGALLO, H.G. 2008b. Mammals, Serra da Concórdia, state of Rio de Janeiro, Brazil. Check List, 4(3): 341-348.

MORATELLI, R. \& PERACCHI, A. L. 2007. Morcegos (Mammalia, Chiroptera) do Parque Nacional da Serra dos Órgãos. In Ciência e conservação na Serra dos Órgãos (C. Cronemberger \& E.B. Viveiros de Castro, orgs) IBAMA, Brasília, p. 193-210.

MORATELLI, R., PERACCHI, A.L., DIAS, D. \& OLIVEIRA, J.A. 2011 Geographic variation in South American populations of Myotis nigricans (Schinz, 1821) (Chiroptera, Verpertilionidae), with the description of two new species. Mamm. Biol. 76: 592-607.

NEGRÃO, M.F.F. \& VALLADARES-PÁDUA, C. 2006. Registro de mamíferos de maior porte na Reserva Florestal de Morro Grande, São Paulo Biota Neotrop. 6(2): 1-13 http://www.biotaneotropica.org.br/v6n2/pt/ abstract?article+bn 00506022006 (last access at 18september/2017).

NORRIS, D., RAMIREZ, J.M., ZACCHI, C. \& GALETTI, M. 2012. A survey of mid and large bodied mammals in Núcleo Caraguatatuba, Serra do Mar State Park, Brazil. Biota Netrop. 12(2): 127-133 http://www.biotaneotropica org.br/v12n2/en/abstract? invento

ry+bn00312022012 (last access at 18september2017).

OLIIFIERS, N., CUNHA, A.A., GRELLE, C.E.V., BONVICINO, C.R., GEISE, L., PEREIRA, L.G. VIEIRA, M.V., D'ANDREA, P.S. \& CERQUEIRA, R. 2007. Lista de pequenos mamíferos não-voadores do Parque Nacional da Serra dos Órgãos. In Ciência e conservação na Serra dos Órgãos (C. Cronemberger \& E.B. Viveiros de Castro, orgs) IBAMA, Brasília, p. 183-192.

PARDINI, R. \& UMETSU, F. 2006. Pequenos mamíferos não-voadores da Reserva Florestal do Morro Grande - distribuição das espécies e da diversidade em uma área de Mata Atlântica. Biota Neotrop. (6)2: 1-22. doi: http://dx.doi.org/10.1590/S1676-06032006000200007 (last access a 18september2017)

PAGLIA, A.P., FONSECA, G.A.B, RYLANDS, A.B., HERRMANN, G., AGUIAR, L.M.S., CHIARELLO, A.G., LEITE, Y.L.R., COSTA, L.P., SICILIANO, S., KIERULFF, M.C.M., MENDES, S.L., TAVARES, V.C., MITTERMEIER, R.A. \& PATTON, J.L. 2012. Lista anotada dos mamíferos do Brasil. 2a edição. Occasional Papers in Conservation Biology. No.6. Conservation International. 76p.

PARRY, L., \& C. A. PERES. 2015. Evaluating the use of local ecological knowledge to monitor hunted tropical-forest wildlife over large spatial scales. Ecol. Soc. 20(3): 15.

PESSÔA, F.S., MODESTO, T.C., ALBUQUERQUE, H.G., ATTIAS, N. \& BERGALLO, H.G. 2009. Non-volant mammals, Reserva Particular do Patrimônio Natural (RPPN) Rio das Pedras, municipality of Mangaratiba, state of Rio de Janeiro, Brazil. Check List 5(3): 577-586.

PINHEIRO, P.S. \& GEISE, L. 2008. Non-volant mammals of Picinguaba, Ubatuba, state of São Paulo, southeastern Brazil. Bol. Mus. Biol. Mello Leitão. 23:51-59. 
PERES, C.A. 2001. Synergistic effects of subsistence hunting and habitat fragmentation on Amazonian forest vertebrates. Conserv. Biol. 15: $1490-1505$.

PERES C.A. \& LAKE, I.R. 2003. Extent of nontimber resource extraction in tropical forests: accessibility to game vertebrates by hunters in the Amazon basin. Conserv. Biol. 17: 521-535.

PESSÔA, F.S. 2009. Comunidades de pequenos mamíferos no estado do Rio de Janeiro. Dissertação de mestrado. Universidade do Estado do Rio de Janeiro. Rio de Janeiro.

QUEIROLO, D., MOREIRA, J. R., SOLER, L., EMMONS, L. H., RODRIGUES, F. H. G.,PAUTASSO, A. A., CARTES, J. L. \& SALVATORI, V. 2011. Historical and Present Geographic Distribution of Chrysocyon brachyurus (Carnivora: Canidae). Oryx, 45: 296-303.

RIPPLE, W. J., NEWSOME, T. M., WOLF, C., DIRZO, R., EVERATT, K. T., GALETTI, M., HAYWARD, M. W., KERLEY, G. I. H., LEVI, T., LINDSEY, P. A., MACDONALD, D. W., MALHI, Y., PAINTER, L. E., SANDOM, C. J., TERBORGH, J., VAN VALKENBURGH, B. 2015. Collapse of the world's largest herbivores. Sci. Adv. 1(4): e1400103.

ROCHA, C.F.D., BERGALlO, H.G., POMBAL-JR, J.P., GEISE, L., VAN-SLUYS, M., FERNANDES, R. \& CARAMASCHI, U. 2004. Fauna de anfíbios, répteis e mamíferos do estado do Rio de Janeiro, Sudeste de Brasil. Publi. Avulsas Mus. Nac. 104: 1-24.

ROCHA-MENDES, F., NEVES, C.L., NOBRE, R.A., MARQUES, R.M., BIANCONI, G.V., GALETTI, M. Non-volant mammals from Núcleo Santa Virgínia, Serra do Mar State Park, São Paulo, Brazil. Biota Neotrop. 15(1): 1-9. http://dx.doi.org/10.1590/1676-06032014000814 (last access at 18september/2017).

RUIZ-MIRANDA, C.R., AFFONSO, A., MORAIS, M.M., VERONA, C.E.S., MARTINS, A. \& BECK, B. B. 2006. Behavioral and ecological interactions between reintroduced golden lion tamarins (Leontopithecus rosalia Linnaeus, 1766) and introduced marmosets (Callithrix spp, Linnaeus, 1758) in Brazil's Atlantic Coast Forest fragments. Braz. Arch. Biol. Technol. 49(1): 99-109.
SANTOS, C.S. 2013. Quiropterofauna da Reserva Ecológica de Guapiaçu, Cachoeiras de Macacu, RJ: considerações sobre a composição e a diversidade e comparações com comunidades de morcegos de outras áreas de Mata Atlântica no sudeste do Brasil. Dissertação de mestrado. Universidade Federal do Estado do Rio de Janeiro. Rio de Janeiro.

SCHIRCH, P.F. 1932. Contribuição ao conhecimento da fauna de Therezópolis, 960 m. Bol. Mus. Nac. 8, 77-86.

SRBEK-ARAÚJO, A.C. \& CHIARELLO, A.G. 2005. Is camera-trapping an efficient method for surveying mammals in Neotropical forests? A case study in south-eastern Brazil. J. Trop. Ecol. 21: 121-125.

SRBEK-ARAÚJO, A.C. \& CHIARELLO, A.G. 2007. Armadilhas fotográficas na amostragem de mamíferos: considerações metodológicas e comparação de equipamentos. Rev. Bras. Zool. 24(3): 647-656.

SILVA, L.D. \& M. PASSAMANI. 2009. Mamíferos de médio e grande porte em fragmentos florestais no município de Lavras, MG. Ver. Bras. Zoociências, 11(2): 137-144

SILVEIRA, E.K.P. 1968. Notas sobre a fauna original de vertebrados florestais nos maciços montanhosos da Guanabara. Boletim Geográfico, 203: 67-83.

SPIX, J.B.V. \& MARTIUS, C.F.P. 1981. Viagem pelo Brasil: 1817-1820, $4^{\mathrm{a}}$ edição. 46, volume I. São Paulo: Livraria Itatiaia Editora/Editora da Universidade de São Paulo. 264 pp.

TONINI, J.F.R., CARÃO, L.M., PINTO, I.S., GASPARINI, J.L., LEITE, Y.L.R. \& COSTA, L.P. 2010. Non-volant tetrapods from Reserva Biológica de Duas Bocas, State of Espírito Santo, Southeastern Brazil. Biota Neotrop. 10(3): 339-351. http://www.biotaneotropica.org.br/v10n3/en/abstract?inventory+ bn02710032010 (last access at 18september2017).

TRAVASSOS, L. 2011. Impacto da sobrecaça em populações de mamíferos e suas interações ecológicas nas florestas neotropicais. Oecol. Aust. 15(2): 380-411.

TRIBE, C.J., 1987, A mastofauna do Estado do Rio de Janeiro, com especial referência à ordem Polyprotodontia (Marsupiais). Universidade Federal do Rio de Janeiro/Museu Nacional. Rio de Janeiro.

VAZ, S.M. 1984. Lista Preliminar sobre os Mamíferos Existentes na Serra do Tinguá. Bol. FBCN 19: 749-154.

XAVIER, M.S., LEMOS, H.M., CACCAVO, A., BEZERRA, A., SECCO, H. \& GONÇALVES, P.R. 2017. Noteworthy coastal records of the maned wolf, Chrysocyon brachyurus (Illiger, 1815), in Southeastern Brazil. BOL. SOC. BRAS. MASTOZOOLOGIA, v. 78, p. 9-13. 